\title{
Acropectoral syndrome
}

INSERM

\section{Source}

INSERM. (1999). Orphanet: an online rare disease and orphan drug data base.

Acropectoral syndrome. ORPHA:85203

Acro-pectoral syndrome is characterized by a combination of distal limb abnormalities

(syndactyly of all fingers and toes, preaxial polydactyly in the feet and/or hands) and upper sternum malformations. It has been described in 22 patients from a six-generation Turkish family. It is transmitted as an autosomal dominant trait and the causative gene is located at $7 \mathrm{q} 36$. 